\title{
Research on the Contemporary Group Company Financial Control Mode from the Perspective of Subsidiary Management and Control
}

\author{
Jie Li \\ Xijing University, \\ Xi'an,Shaanxi,710123 China
}

\begin{abstract}
In this paper, we conduct research on contemporary group company financial control mode from the perspective of the subsidiary management and control. The fundamental nature of enterprise is that it is a kind of effective mechanism to create wealth governance and management are part of the effective mechanism, a combination of both make up the enterprise system. Corporate governance and management are mutually restricts and the influence each other. Strategic management is also the connection of both its purpose is to better realize the long-term and short-term interests of the wealth creation process. Our research starts from the analysis of the financial control to form the better way of managing the subsidiary which holds great importance.
\end{abstract}

Keywords- Group Company, Financial Control, Subsidiary Management, Perspective.

\section{Introduction}

Enterprise and the market is the allocation of resources can replace each other and the existence of enterprise because it can save transaction cost, which can replace with the market mechanism. The operation of the market has a cost, and the emergence of enterprise can use its authority relationship, by reducing the number of transactions, to achieve more effective than the market mechanism of the resource allocation. The difference mainly reflects in, the market is the spontaneous run through the impersonal price mechanism, and within the enterprise, is by the bureaucratic organization structure on the basis of administrative authority, the choice of both depending on the market transaction cost and the balance between the administrative authorities of implementation cost.
Enterprise group is a kind of important organization form of modern enterprise, large enterprise groups in China has made significant development in recent years. Financial control is the foundation of corporate governance and security is a group company to implement the important content of the internal management and control. Enterprise group financial control level determines the enterprise group can play a good synergy as determine the sustainable and healthy development of the enterprise group in the future. Subject the financial control of enterprise group is a group company, in certain circumstances, by way of financial management of the whole group of kinematic chain towards group company value maximization goal of development [1-3].

Enterprise group internal relationship is essence of the parent company and other members of the company of principal-agent relationship, business operator entrusted agency authorized by business owners to exercise management control of the enterprise. According to the literature review, the core relationship between the corporate governance and financial management could be summarized as the follows. (1) The establishment of corporate governance through rules affects company management. The foundation of the corporate governance in terms of system acts as a management and corporate governance to enterprise's development direction, organization, distribution of power and operation, profit distribution of general rules, and equivalent rules for general managers to determine behavior and managers decided to basic strategy and action according to rules. (2) Top managers in corporate governance and corporate management in two areas, their 
position decision, order management, the role is very important. As the core of corporate governance of the board of directors is the standing of small diameter of shareholder in enterprise governance structure, role is to supervise the management of the board of directors. (3) Determine the company's business philosophy and mission, review and approve management strategic plan and the business plan, including a more detailed understanding of development to do business, understand and questioned these plans premise, based on which the form to realize the possibility of the independent judgment to the plan, which suggests that when making strategic decisions while the company governance body plays the decisive role. (4) The efficient and effective operation of the company management needs the necessary power. Each of the participants to pursue their own interests to maximize, managers also is one of them. Corporate governance can be achieved by design incentive contracts for management people create dynamic performance [4].

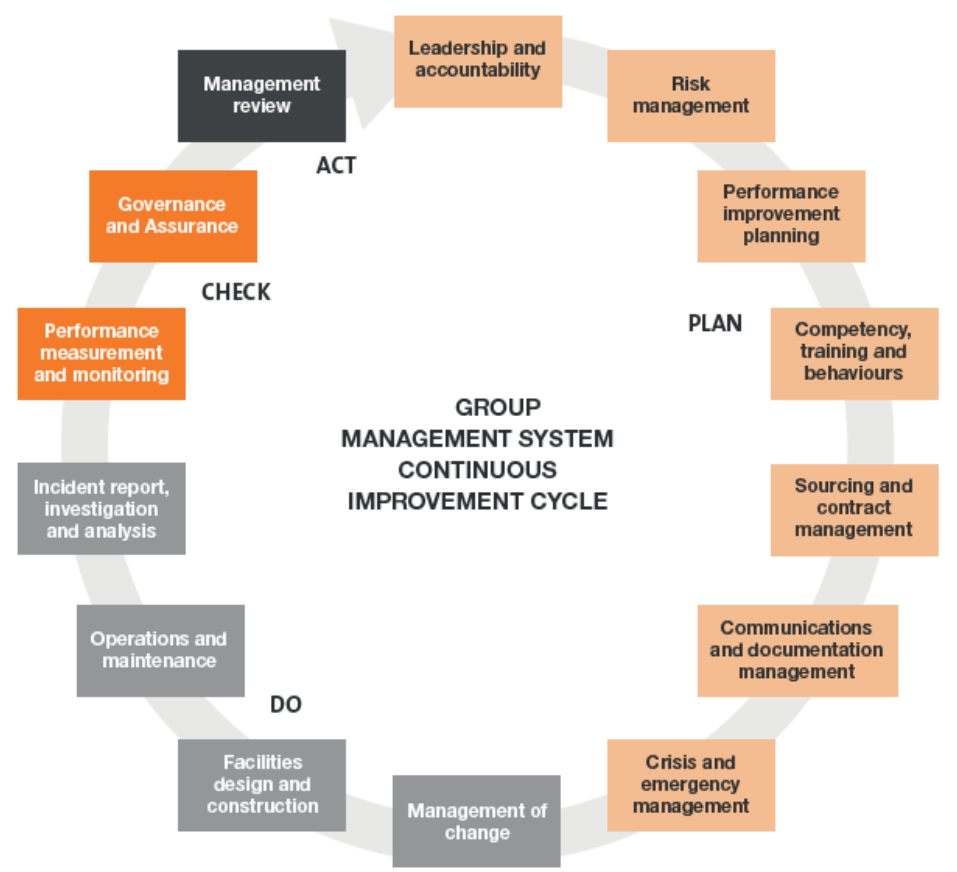

Figure 1. The General Circle for the Group Company Management

In this paper, we conduct research on contemporary group company financial control mode from the perspective of subsidiary management and control. In the later sections, we will discuss the related issues in detail with corresponding empirical analysis.

\section{Our Proposed Methodology}

The Characteristics of Group Company. The interests of the group, there is a very complicated relationship, when the management behavior of group company damage to the interests of either party may cause the failure of contractual relationship, thereby threatening the survival and development of group companies. Group company is under the contract parties "force" the survival and development, in order to coordinate the interests of all parties, and the relationship between the interests of all the parties given conditions, to maximize the interests of all parties, the group company should strengthen the centralized management of funds, only by doing so, to a greater degree of avoid the independent group subsidiaries, parent company caused by poor regulation and the core phenomenon of internal control, more long-term benefits from the enterprise development to take care of the 
interests of all parties, avoid to benefit the one side and the other a damaged interests [5-6].

According to the group company's overall control mode selection and marketing decision of the separation of powers, in the different parent-subsidiary control mode under general different channel management responsibilities which could be summarized as the following aspects. (1) The model of governance. Type management mode, group company is mainly responsible for channel management in major matters of the decision-making, such as basic channel overall goal, channel development, the major adjustment basic policy, channel, channel planning, annual plan and important activities, etc., and subsidiaries channel planning and provide guidance and advice as all the subsidiary must strictly implement the group company channel management, making major decisions and is responsible for the organization daily decision-making and implementation of channel management. (2) Independent management mode. Independent management mode, the unit has the channel management autonomy, according to the internal and external environment to make channel planning, and submitted to the group audit, for record. A subsidiary company basic not to interfere in specific channel management work, mainly responsible for channel execution supervision and basic assessment of subsidiaries as subsidiary in channel strategy implementation process, according to the internal and basic external environment changes to adjust channel. (3) The administrative management mode. Administrative management mode is usually adopts the vertical management group company, the group company is responsible for the channel decision-making work across all units, subsidiaries only responsible for coordination group of companies do a good job in the implementation of relevant and timely feedback to the group company in the process of implementation of the implementation [7].

The Principles of Company Financial. Within the enterprise power, responsibility, according to the principle of basic mutual incentive and restriction to establish the modern corporate governance structure, the so-called corporate governance structure is a kind of contract system, it through certain means of governance, the rational allocation of residual claims and control, forming self-constraint mechanism and the mechanism of checks and balances. From a financial point of view, the company must establish corresponding corporate financial governance structure corporate financial governance structure, including the reasonable structure of property rights separation of the financial management system and the content of the incentive and constraint mechanism for the financial manager.

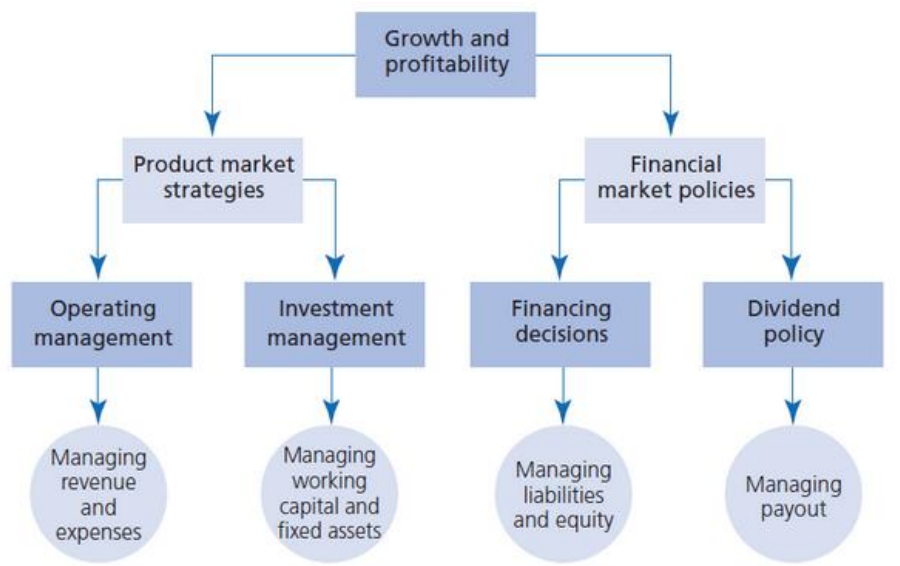

Figure 2. The Architecture of the Modern Company Financial System 
As shown above, we illustrate the modern company financial system. Based on the theory of basic internal control all aspects of financial risk, is the objective existence of a variety of difficult or unable to predict and control factors, such as financial policy, financial operation and financial management aspects of inappropriate behavior and lead to the risk of financial results and financial condition. To deal with this condition, we propose the following suggestions.

- Stakeholders in the financial governance structure in the role of incentive and constraint. In perfecting the market economy condition, the restraint to the company by stakeholders in the financial constraints and the capital market, manager market, the common role of banking institutions, and other constraint mechanism, to realize the two rights separation control of the company business, under condition of guarantee the fundamental interests of the stakeholders.

- The operator financial dominant position and the link role in governance structure. Under the condition of the two rights separation, to obtain the legal person property rights, making the business operators have direct control of capital operation, which makes control acquired enterprises become the subject of an independent financial dominant position in the enterprise financial operators.

- Financial manager is the foundation of all financial activities of the enterprises and the starting point, generally involves cash management, financing, credit management, profit distribution, financial forecasts, plans, etc., that is basic logistics in the corporate governance and the main source of information of value and is the prerequisite of other normal financial activities.

Establish and improve the general company's financial governance structure, which is beneficial to improve the efficiency of corporate financial decisions, perfect the corporate governance structure, to accelerate the construction of the modern enterprise system. It to our country state-owned enterprise financial system innovation as provides a new train of thought, the purpose of the modern company internal financial system innovation which is to build efficient, dynamic and compatible incentive constraints of corporate financial governance structure [8].

The Subsidiary Management and Control. Modern enterprise in order to be able to gain the economies of scale, will usually choose group management mode, so that we can give priority to with corporation, subsidiary, obey the arrangement of the company, but because each group of products and staffing levels are quite different, so each group company used by the management mode is very different, but generally speaking as there are three kinds of management pattern's most widely used.

How group company established in accordance with company law and the company management system, and the subsidiary company exercise investor rights according to law, standardize the internal management of parent-subsidiary corporate, in recent years has been the enterprise theory to discuss the new project. Therefore, the following suggestions are correspondingly proposed. (1) The strategic control type, this type of group, the group corporation on the basis of existing assets operation to make strategic planning and development, and also develop their own strategic planning, each subsidiary needed to make the goal to achieve for the budget at the same time, the group head office after the audit, for approval and the suggestions are put forward. (2) Financial control mode, the company is mainly financial statements of subsidiaries and investment decisions of management, its subsidiary company as long as their own financial goal is to report to head office, and can be made within the time limit specified by the 
target. (3) Operation control model, this model is a group company in detail for any of the items is subsidiaries to manage the companies to standardize the behavior of ensure the interests of the group can be achieved.

The Future of Company Management. From the perspective of the modern management, the innovation is an important management function. However, management innovation could be too much of a risk, even if a successful project also tends not to have profit in the short term. If innovation failure, managers could bear corresponding responsibility, so not all managers are willing to engage in innovative activities. Theoretical studies show that the corporate governance affects the management innovation activities. We argue that the corporate governance, corporate management and enterprise innovation formed between transmission chain, without influence of corporate governance, managers will tend to be conservative and the enterprise innovation activity will slow.

Corporate governance structure to open some control activities, used to supplement management control activities, such as the responsibility of the board of directors include some issues related to the control: monitor and evaluate top management work, the company's performance compared with the strategic plan and basic business plan monitoring, by operating results on a regular basis to evaluate whether the company's business to obtain the very good management, to ensure that the enterprise behavior following the audit and accounting standards and the company's own management files. In addition, the board of directors has an audit committee, internal control of enterprise.

\section{Conclusion}

In this paper, we conduct research on contemporary group company financial control mode from the perspective of the subsidiary management and control. Corporate governance problem is, in fact, the shareholders and the board of directors, board of directors and general manager of the principal-agent relationship between the problems. Principal-agent relationship is a kind of contractual relationship, under this contract, one or more people to hire another person or more people to represent them to provide certain services, including the number of the decision-making power delegated to the agent. Corporate governance including expressly provide responsibilities of the company each participant and rights distribution, such as the board of directors, managers, shareholders and other stakeholders, and clearly shows that when making decisions on company issues which should be followed by the rules and procedures. Our research combines the state-of-the-art perspectives on the related theories to propose the novel paradigm for the subsidiary management and control.

\section{References}

[1] Singh, Deeksha. "Emerging economies and multinational corporations: An institutional approach to subsidiary management." International Journal of Emerging Markets 7.4 (2012): 397-410.

[2] Filippov, Sergey, and Geert Duysters. "Exploring the drivers and elements of subsidiary evolution in several new EU member states." International Journal of Emerging Markets 9.1 (2014): 120-146.

[3] Phene, Anupama, and Sali Li. "Knowledge leveraging in the MNC: A study of subsidiary-headquarters innovation collaboration." Academy of Management Proceedings. Vol. 2015. No. 1. Academy of Management, 2015.

[4] Griffith, David A., Timothy Kiessling, and Marina Dabic. "Aligning strategic orientation with local market conditions: Implications for subsidiary knowledge management." International Marketing Review 29.4 (2012): 379-402. 
[5] Blomkvist, Katarina. "Knowledge management in MNCs: the importance of subsidiary transfer performance." Journal of Knowledge Management 16.6 (2012): 904-918.

[6] Contractor, Farok J., Yong Yang, and Ajai S. Gaur. "Firm-Specific Intangible Assets and Subsidiary Profitability: The Moderating Role of Distance." Academy of Management Proceedings. Vol. 2013. No. 1. Academy of Management, 2013.

[7] Garavan, Thomas N. "Global talent management in science-based firms: an exploratory investigation of the pharmaceutical industry during the global downturn." The International Journal of Human Resource Management 23.12 (2012): 2428-2449.

[8] Chen, Homin, and Chia-Wen Hsu. "Internationalization of Taiwanese manufacturing firms: The evolution of subsidiary mandates and capabilities." Asian Business \& Management 12.1 (2013): 37-60. 